\title{
Cross-reactivity of antibodies from non-hospitalized COVID-19 positive individuals against the native and B.1.351 SARS-CoV-2 spike proteins
}

Maryam Hojjat Jodaylami

Université de Montréal

Abdelhadi Djaileb

Université de Montréal

Pierre Ricard

Université de Montréal

Etienne Lavallée

Université de Montréal

Stella Cellier-Goetghebeur

Université de Montréal

Julien Coutu

Université de Montréal

Matthew Stuible

National Research Council of Canada

Christian Gervais

National Research Council of Canada

Yves Durocher

National Research Council of Canada

Marie-Pierre Cayer

Héma-Québec

Marie Joelle De Grandmont

Héma-Québec

Samuel Rochette

Héma-Québec

Danny Brouard

Héma-Québec

Sylvie Trottier

CHU Laval

Denis Boudreau

Université Laval

Joelle Pelletier ( $\square$ joelle.pelletier@umontreal.ca ) 
Université de Montréal

Jean-Francois Masson ( $\sim$ jf.masson@umontreal.ca )

Université de Montréal

\section{Methods Article}

Keywords: SARS-CoV-2, ELISA, Surface plasmon resonance (SPR), antibody, immunity, variants of concern, coronavirus, pseudo-neutralization, B.1.351

Posted Date: June 21st, 2021

DOI: https://doi.org/10.21203/rs.3.rs-646031/v1

License: (9) This work is licensed under a Creative Commons Attribution 4.0 International License. Read Full License 


\section{Abstract}

SARS-CoV-2 variants of concern (VOCs) have emerged worldwide, with implications on the spread of the pandemic. Characterizing the cross-reactivity of antibodies against these VOCs is necessary to understand the humoral response of non-hospitalized individuals previously infected with SARS-CoV-2, a population that remains understudied. Thirty-two SARS-CoV-2-positive (PCR-confirmed) and nonhospitalized Canadian adults were enrolled 14-21 days post-diagnosis in 2020, before the emergence of the B.1.351 VOC (also known as Beta). Sera were collected 4 and 16 weeks post-diagnosis. Antibody levels and pseudo-neutralization of the ectodomain of SARS-CoV-2 spike protein/human ACE-2 receptor interaction were analyzed with native and B.1.351 variant spike proteins. Despite a lower response observed for the variant spike protein, we report evidence of a sustained humoral response against native and B.1.351 variant spike protein among non-hospitalized Canadian adults. Furthermore, this response inhibited the interaction between the spike protein variant of concern and ACE-2 receptor for $\geq 16$ weeks post-diagnosis.

\section{Introduction}

The severe acute respiratory syndrome coronavirus 2 (SARS-CoV-2) has infected and caused the death of millions of individuals across the globe since 2019 (1). This RNA coronavirus of zoonotic origin has a diameter of 80-90 nm with several structural proteins, including nucleocapsid and spike (2). The virus invades and replicates in the lower respiratory tract and causes pneumonia in some infected individuals, which is one of the most frequent complications of the coronavirus disease COVID-19.

The immune system fights the infection by eliciting an innate immune response (3), and a B-and T-cell mediated response $(4,5)$. The humoral response against SARS-CoV-2 follows a classical pattern in which IgMs and IgAs are expressed 1-2 weeks post-diagnosis during the recovery phase and IgGs are expressed 2-4 weeks post-diagnosis during the convalescence phase $(6,7)$. IgGs may be associated with long-term humoral memory as they are detectable several months post-diagnosis (8). However, antibody levels appear to be lower for asymptomatic or paucisymptomatic individuals compared to those with severe illness requiring hospitalization (9-11). Given this notable difference, studies are needed to better understand the humoral response of non-hospitalized individuals, a population that remains understudied.

As an abundant surface protein with a large, accessible ectodomain, spike protein is the immunogen of SARS-CoV-2 that elicits the strongest humoral response. As a result, the ectodomain of spike protein (simply referred to as 'spike protein' here) forms the basis of current mRNA and viral-vector based vaccines $(12,13)$. Spike is a trimeric glycoprotein with each monomer composed of an S1 and S2 subunit. During viral fusion with human cells, the receptor binding domain (RBD) of the $\mathrm{S} 1$ subunit binds to the membrane-bound angiotensin-converting enzyme 2 (ACE-2) (14), and the S2 subunit mediates membrane fusion. ACE-2 is particularly abundant on the surface of lower respiratory tract cells, which makes them susceptible to infection and can cause pneumonia $(15,16)$. The antibodies produced in 
response to current vaccines work primarily by binding to the RBD of spike protein, thus blocking its interaction with ACE-2 (17), which is thought to mediate their effectiveness.

Over the course of the pandemic, several SARS-CoV-2 variants of concern (VOCs), including the B.1.351 variant (also named Beta variant by the WHO), have emerged and become the dominant strains in Canada and throughout most of the world. These variants harbor mutations in the ectodomain of spike protein, which raises questions about the effectiveness of the humoral immunity acquired by individuals who were previously infected with the native reference strain that originated from Wuhan, China (i.e., variant-naïve individuals), and following immunization. These mutations may affect the ability of antibodies to bind to the virus which may thus evade neutralizing antibodies (18-20). It has been reported that the N501Y, E484K and K417N mutations of B.1.351 VOC spike protein reduce the activity of antibodies from convalescent plasma or therapeutic monoclonal antibodies (21-24). It is suspected that the multiple mutations harbored by B.1.351 spike protein could lead to a conformational change in the RBD of spike and affect binding to ACE-2 (25). Detailed investigations of the cross-reactivity of antibodies are therefore necessary to evaluate the susceptibility of individuals to infection by the B.1.351 VOC, particularly those infected early during the pandemic as well as those immunized, all of whom are thus presumably naïve to these variants.

Several methodological approaches are available to study the humoral response against SARS-CoV-2. Most serological assays use ELISA to assess the seroprevalence of SARS-CoV-2. These assays typically detect IgGs targeting the $\mathrm{S} 1$ subunit or the trimeric spike protein, which improves performance compared with assays that target the RBD (26). However, detecting anti-spike IgGs alone provides an incomplete picture of the humoral response, as effective antibodies should inhibit the interaction of spike protein with ACE-2 $(27,28)$. Cell-based neutralization assays are the gold standard but require live viruses and thus a biosafety level 3 (BSL3) lab, which makes these assays costly, complex and lengthy to perform. Cell- and virus-free surrogate or pseudo-neutralization assays could provide valuable functional information on the inhibition of the interaction between spike protein and ACE-2, as recently demonstrated by a surrogate ELISA neutralization assay (29). Sensing techniques such as surface plasmon resonance (SPR) provide complementary biochemical data to ELISA. SPR has been used to conduct serological tests (30) and to measure various biochemical parameters influencing the strength of the humoral response, including the binding constant of the antibodies to spike or its subunits (37), the inhibition of the spike protein:ACE-2 interaction by neutralizing antibodies $(32,33)$ and the equilibrium dissociation constant $\left(K_{D}\right)$ of recombinant human ACE-2 with the RBD of spike protein (34).

In this longitudinal study, we assessed the cross-reactivity of antibodies produced by non-hospitalized, variant-naïve SARS-CoV-2-positive individuals against the native and B.1.351 VOC spike proteins. Notably, an in vitro SPR pseudo-neutralization assay was developed to determine the ability of convalescent sera to inhibit the interaction between native and B.1.351 spike proteins and ACE-2.

\section{Results}


Serum samples from 32 non-hospitalized individuals who tested positive for SARS-CoV-2 (PCR confirmed) were collected at weeks 4 and 16 post-diagnosis. Inclusion criteria included quotas based on age, so that the cohort consisted of four age groups (18-49, 50-59, 60-69 and 70+ years) that each comprised eight individuals. Control sera were collected from eight individuals never diagnosed with SARS-CoV-2. Of note, one individual aged 60-69 years did not report on week 16 ( $n=7$ for this age group).

Antigen-down colorimetric ELISA and SPR assays were adapted from the previously reported protocols $(11,30,35,36)$ to detect IgGs targeting the B.1.351 spike protein. ELISA operates at a greater dilution factor (1:50) compared to SPR (1:5). Therefore, ELISA preferentially measures high concentration and high affinity (high $\mathrm{K}_{\mathrm{D}}$ ) antibodies, whereas SPR measures both high and low concentration or high and low affinity antibodies.

ELISA performed well to identify SARS-CoV-2-positive individuals from the negative control group based on the native spike protein ( $A U C=1.00$ and $p<0.0001$ ), correctly identifying all positive and negative samples (sensitivity $=100 \%$, specificity $=100 \%$, Tables 1 and S1). The SPR assays also performed well for the native spike protein (AUC $=0.99$ and $p<0.0001$ ), correctly identifying all samples with the exception of one positive sample which tested negative at week 4 (sensitivity $=97 \%$, specificity $=100 \%$, Tables 2 and S2). Whereas the $\mathrm{OD}_{450}$ decreased by approximately $20 \%$ from weeks 4 to 16 for the native spike protein, the SPR binding shift did not change significantly (Figure 1). The ELISA OD 450 and the SPR shift tended to decrease for B.1.351 at weeks 4 and 16 in comparison to the native spike protein, the greatest difference being week 4 (Figures 1 and S1). As a result, a few positive samples tested negative when SPR assays were conducted with the B.1.351 spike variant (Table 2), which affected the AUCs (range: $0.82-0.96)$ to detect positive samples from the negative controls, especially on week $4(p<0.05$, Figure S2). However, the performance of ELISA remained excellent (AUC: 1.00 and $p<0.0001$ for B.1.351, Table 1, Figure S3). Nonetheless, each method showed a positive signal for at least 26 of the 32 SARSCoV-2-positive samples with SPR and all samples in ELISA, indicating that antibodies arising from an infection with the native strain cross-reacted with the B.1.351 spike protein, as reported in a previous report (37).

ELISA and SPR experiments were then repeated with the RBD of native and B.1.351 spike. However, the ability of the RBD assays to discriminate between positive to negative samples was generally lower than that obtained using full-length spike protein (Figures S4 to S6 and Tables S3 to S6, compared to Tables 1 and 2), in agreement with previous reports in which using the $\mathrm{S} 1$ subunit or trimeric spike ectodomain protein improved assay performance $(2,26,38)$. Therefore, the full-length spike protein was used for the remaining experiments. Taken together, these results suggest that the sera of variant-naïve, SARS-CoV-2positive individuals contain antibodies that cross-react with the B.1.351 spike variant during at least 16 weeks post-diagnosis, although antibody binding appeared reduced for this variant compared with the native protein (Figure 1). 
When stratified by age, antibody binding increased with age for native spike, and this trend was even more evident for the B.1.351 spike VOC (Figure 2). On average, individuals in the 70+ years group exhibited ELISA or SPR responses 15\% (native) to 30\% (B.1.351) above the mean of the overall cohort, those aged $50-59$ or $60-69$ years exhibited responses within $10 \%$ of the mean, and those aged $18-49$ years exhibited responses $18 \%$ (native) to $30 \%$ (B.1.351) below the mean.

Label-free response and affinity of antibodies produced by variant-naïve individuals against native and variant spike proteins

SPR sensing is ideally suited for the measurement of antibodies and proteins in moderately diluted (i.e., 1:10) to undiluted serum.(39) Because SPR is a label-free method, it can be used to study biochemical properties of protein-protein interactions, such as the $K_{D}$. Prior studies have successfully used SPR to study the affinity of antibodies produced following SARS-CoV-2 vaccination(40) or COVID-19 infection (31). Hence, we adapted the SPR assay to measure antibody binding and affinity based on the sera of four SARS-CoV-2-positive individuals aged 18-49 years (Figure S9).

The SPR binding shift for the undiluted sera remained constant between weeks 4 and $16(p=0.83)$ for the native and B.1.351 ( $p=0.73$ ) spike proteins (Figure 3). This constant SPR response is consistent with data reported in Figure 1 where the SPR binding shift (albeit for 1:5 dilution and with a secondary assay) was also similar between weeks 4 and 16 for the native $(p=0.47)$ and B.1.351 $(p=0.34)$ spike proteins. The SPR binding shift tended to decrease from weeks 4 to 16 when using a 1:20 dilution for native $(p=0.06)$ and B.1.351 ( $p=0.11)$ spike proteins, likely because SPR primarily detects high affinity antibodies in highly diluted samples. As shown earlier, a similar decrease was obtained using ELISA (Figure 1), which was also performed using samples at a greater dilution (1:50). For the B.1.351 variant, the SPR signal appeared modestly lower (although not statistically significant at week 16) than that observed for native spike at week $4(p=0.04)$ and week $16(p=0.08$; Figure 3$)$.

The label-free SPR assay revealed that binding shift increased almost linearly with serum dilution (Figure $S 9$ - left panel), and $K_{D} S$ were extracted by fitting a 1:1 binding site Langmuir isotherm (Figure $S 9$ - right panel). Because the serum concentration is expressed in dilution factor (i.e., a high dilution factor corresponds to low antibody levels), a high $\mathrm{K}_{\mathrm{D}}$ corresponds to a high affinity of the antibodies for spike. Attempts to extract the association $\left(k_{o n}\right)$ and dissociation $\left(k_{\text {off }}\right)$ rates were unsuccessful since sera contained a mixture of polyclonal antibodies. The estimated $K_{D}$ appeared to decrease for the two spike proteins, but the difference was not statistically significant (native: $p=0.11$ and B.1.351: $p=0.29$ ) from weeks 4 to 16 (Figure 3 - right panel). No difference in $K_{D}$ was observed between native and B.1.351 spike proteins at week $4(p=0.48)$ and week $16(p=0.54)$.

\section{Pseudo-neutralization SPR inhibition assay}

To better understand the potential functional implications of antibody cross-reactivity, we adapted a previously reported in vitro pseudo-neutralization assay $(32,41)$ to measure how antibody binding to 
spike protein affects its interaction with ACE-2 (details in supporting information, Schemes S1 and S2, Figures S10 to S12 and Tables S7 and S8). The difference in inhibition of the spike-ACE-2 interaction between weeks 4 and 16 post-diagnosis was not statistically significant for native (mean inhibition \%: week $4=59 \%$, week $16=57 \%, p=0.67$ ) and B.1.351 spike proteins (week $4=41 \%$, week $16=36 \%, p=$ 0.1 ; Tables S9). Sera from variant-naïve SARS-CoV-2-positive individuals inhibited the spike-ACE-2 interaction significantly less for B.1.351 than native spike protein at week 4 (native $=59 \%, B .1 .351=41 \%$, $p<0.0001$; Figure 4 and Table S9) and at week 16 (native $=57 \%$, B.1.351 $=36 \%, p<0.001$; Figure 4 and Table S9). No difference in inhibition was observed between female and male individuals for the native (females $=55 \%$, males $=61 \%, p=0.37$ ) and B.1.351 (females $=35 \%$, males $=44 \%, p=0.10)$ spike proteins (Figure 4). The percent inhibition observed for each individual only had a mild correlation between native and B.1.351 spike proteins ( $r=0.46$; Figure 4). However, the percent inhibition correlated well with the ELISA $\mathrm{OD}_{450}$ results (native: $r=0.70 ; \mathrm{B} .1 .351: r=0.61$ ), suggesting that anti-spike IgG concentration is a significant driver of the inter-individual variation in the ability of sera to inhibit the interaction between spike protein and ACE-2 (Figure 4).

\section{Discussion}

The protein-protein interaction data reported in this study show cross-reactivity of antibodies produced by variant-naïve, SARS-CoV-2-positive (PCR-confirmed) individuals against the B.1.351 VOC. Notably, none of the SARS-CoV-2-positive individuals included in this study experienced severe symptoms that required hospitalization; this population remains understudied in the existing literature.

Age correlated well with antibody binding: individuals aged 70+ years generally had higher than average ELISA $\mathrm{OD}_{450}$ and SPR responses, those younger than 49 years exhibited below average responses, and those aged 50-69 years exhibited intermediate responses (Figure 2). Other studies also found that age is positively correlated with antibody levels as measured by ELISA among individuals hospitalized for COVID-19 (42) or any cause (whether it be COVID-19 or any other condition) (43). Our study builds on this evidence by showing a similar correlation for the B.1.351 spike VOC.

ELISA and SPR signals were higher against native spike protein than B.1.351 spike protein (Figure 1, Tables 1 and 2), which was expected given that these individuals contracted SARS-CoV-2 early during the pandemic, prior to reports of any VOC and were thus presumably infected with the native strain. Moreover, the higher ELISA and SPR signals were also expected given the larger number of mutations affecting the RBD of B.1.351 spike protein (37). A report suggested that antibodies produced by variant-naïve individuals cross-reacted with the B.1.351 spike, but at lower titer (44). In both cases, these previous results are in agreement with our results.

Sera were collected at 4 and 16 weeks post-diagnosis to evaluate the persistence of the humoral response. The ELISA signal decreased between weeks 4 and 16 for native spike protein, whereas no difference was observed for B.1.351 spike protein. In contrast, SPR responses remained largely unchanged at weeks 4 and 16 for native and B.1.351 spike proteins. This apparent discrepancy between 
ELISA and SPR was due to the different dilution factors used in ELISA (1:50) and SPR (1:5). Indeed, the results of label-free SPR experiments performed at a higher dilution of 1:20 concurred with those of ELISA experiments, with a reduced SPR signal observed at week 16 (Figure 3). Furthermore, $\mathrm{K}_{\mathrm{D}} \mathrm{s}$ (expressed in units of dilution) were appeared to be higher at week 4 than week 16 for native and B.1.351 spike, which suggest a greater affinity of antibodies to all the spike proteins tested earlier post-diagnosis. Taken together, these results provide evidence that the affinity of antibodies wanes between weeks 4 and 16 post-diagnosis, and that antibody binding levels were lower in sera of individuals 16 weeks postdiagnosis. These data also confirm that the sera of variant-naïve, SARS-CoV-2-positive individuals contain anti-spike antibodies that effectively cross-react with B.1.351 spike up until at least 16 weeks post-diagnosis, which is in agreement with other reports $(8,45-49)$.

While informative, biochemical data on antibody binding provide only a partial picture of the humoral response. The pseudo-neutralization SPR assay showed that convalescent sera effectively inhibited the interaction between ACE-2 and the native or B.1.351 spike proteins. Furthermore, the degree of inhibition correlated with the observed ELISA response for anti-spike protein IgGs (Figure 4), suggesting that antibody levels explain a large proportion of the inter-individual variation in the ability of sera to inhibit the spike-ACE-2 interaction. As the ELISA response was higher for the native protein, inhibition of this interaction was more important for the native spike protein. Other reports found that the levels of neutralizing antibodies decreased within 3 months post-diagnosis (46,50-52), which was not seen here in non-hospitalized individuals. One of those reports associated IgMs with improved neutralization early post-diagnosis (50). While such association with antibody isotype cannot be established with our data, the decrease in $\mathrm{K}_{\mathrm{D}}$ and antibody levels from weeks 4 to 16 post-diagnosis tend to support that antibody affinity is more efficient shortly after infection. These results suggest that antibodies from convalescent sera can inhibit the interaction of spike protein with ACE-2, although the degree of inhibition was larger for native spike protein given that included individuals were presumably infected with the native strain of SARS-CoV-2.

This study has some limitations, including the limited number of enrollees and the small number of time points assessed post-diagnosis. Testing the cross-reactivity of the humoral response to the spike proteins of other VOCs is necessary. Increasing sample size should improve the representativeness for some of the experiments. Furthermore, it remains unclear whether ELISA and SPR data may be used to predict the effectiveness of an individual's humoral response to prevent a new infection, whether from the same viral strain of from a variant strain, since clinical outcomes following a subsequent SARS-CoV-2 exposure were not collected. As vaccination progresses, this question will also apply to immunized individuals. Despite the in vitro nature of these experiments, cell-based assays should yield largely similar results since the results of another in vitro, surrogate neutralization assay were found to strongly correlate with those of a cell-based neutralization assay $(29,53,54)$.

In conclusion, antibodies in sera of SARS-CoV-2-positive, variant-naïve individuals cross-reacted with the spike protein of the B.1.351 VOC, albeit with a decrease in antibody binding as measured by ELISA and SPR. Antibody levels decreased from weeks 4 to 16 and were positively correlated with age. SPR results 
suggested that the higher affinity and higher concentration antibodies wanes from weeks 4 to 16 postdiagnosis. However, remaining antibodies effectively inhibited the interaction between native and variant spike proteins and recombinant human ACE-2. ELISA results correlated with the degree of inhibition, suggesting that high antibody levels are needed for optimal pseudo-neutralization. Taken together, these results suggest that variant-naïve, non-hospitalized, SARS-CoV-2-positive individuals have sustained humoral immunity at later times post-diagnosis.

\section{Experimental Section}

\section{Materials}

N-Ethyl-N'-(3-dimethylaminopropyl)carbodiimide hydrochloride, (EDC, crystalline, cat. no. E6383), Nhydroxysuccinimide (NHS, 98\%, cat. no. 130672), ethanolamine hydrochloride ( $\geq 99.0 \%$, cat. no. E6133), glycine hydrochloride ( $\geq 99.0 \%$, cat. no. G2879), bovine serum albumin ( $\geq 98.0 \%$, cat. no. 5470 ),

Tween20 (cat. no. P1379), and human AB serum (cat. no. H4522) were obtained from Sigma Aldrich. The running buffer was composed of phosphate buffer saline 1X (VWR, cat. no. L0119), 0.1\% BSA, and 0.005\% Tween20. Goat anti-human IgG (Jackson Immunoresearch, cat. no. 109-005-003) and human recombinant ACE-2 (Sino Biologicals, cat. no. 10108-H08H) were obtained from commercial sources. Native (PR01-429 (SmT1-1 (55)) and B.1.351 (PRO6429-1 (SmT1 (SA))) spike proteins and biotin-ACE-2 (PR05436-5 (SH6F-ACE2-BAP)) were obtained from the National Research Council of Canada and expressed based on the protocols reported elsewhere (56).

\section{ELISA assays}

Semi-quantitative ELISA was performed based on the protocols of Krammer and of Finzi and Bazin (11, $36,57)$, as recently reported (30). The sera were heat inactivated for 60 minutes at $55^{\circ} \mathrm{C}$ in a heating block and diluted 1:50 before use.

\section{SPR measurements for IgG detection}

The methods for the SPR detection of human IgG antibodies were described recently (30) using a portable SPR instrument (58) (Affinité Instruments, Canada). In brief, after NHS and EDC activation for 2 minutes, the spike ectodomain proteins or RBD for the native strain of SARS-CoV-2 or the B.1.351 variants were immobilized at a concentration of $20 \mu \mathrm{g} / \mathrm{mL}$ for 20 minutes in $\mathrm{pH} 4.5$ acetate buffer and the sensors were washed with $1 \mathrm{M}$ ethanolamine $\mathrm{pH} 8.5$ (10 minutes) and running buffer composed of pH 7.4 PBS $(137 \mathrm{mM} \mathrm{NaCl}, 10 \mathrm{mM}$ phosphate, $2.7 \mathrm{mM} \mathrm{KCl}, \mathrm{pH}$ 7.4) supplemented with $0.1 \%$ bovine serum albumin (BSA) and $0.005 \%$ Tween 20 as described previously. Serum samples were diluted 1:5 in the running buffer and injected for 10 minutes. Following a quick wash with running buffer, secondary detection was performed for 10 minutes with a $40 \mu \mathrm{g} / \mathrm{mL}$ solution for spike and $20 \mu \mathrm{g} / \mathrm{mL}$ for RBD of AffiniPure goat anti-human IgG $(\mathrm{H}+\mathrm{L})$. The surface was regenerated with $10 \mathrm{mM}$ glycine $\mathrm{pH} 2.2$ solution for a few seconds and washed with running buffer before the next set of sera were injected. Experiments were performed with the SPR instrument inside a laminar flow cabinet in a biosafety Level 2 (BSL2) laboratory. 
The SPR instrument had 4 independent channels on the fluidic cell allowing the measurement of up to 4 samples in a single run.

\section{Antibody binding affinity}

For affinity measurements, sera were diluted in the running buffer with dilutions ranging from 1:40 to no dilution (undiluted serum). The sera were then injected sequentially from the greatest dilution to the undiluted sera. Samples were measured in triplicate and the reference channel was used for the background response correction due to nonspecific binding of negative sera at the same dilution factors. In this case, the fluidic cell of the SPR system was identical to that previously described by Zhao et al. (58). Data collected at equilibrium were fit to a single binding site Langmuir model to extract a $K_{D}$ in dilution titer.

\section{Surrogate inhibition assay}

A SPR assay was designed to serve as an in vitro surrogate to cell-based neutralization assay. The spike proteins for the native strain of SARS-CoV-2 or the B.1.351 variant were immobilized on the SPR chip as described above. Following the passivation of the surface with ethanolamine, the SPR sensor was equilibrated in a commercial serum exempt of anti-spike antibody diluted 1:5 in running buffer for typically 10-15 minutes until a stable baseline. Then, different samples were injected on the four channels of the SPR instrument. On two channels, sera from an individual in the negative control group or sera from a PCR-confirmed SARS-CoV-2 infected individual (4- and 16-weeks post infection were tested) diluted 1:5 in running buffer were reacted with the spike protein for 10 minutes. Following a quick wash with running buffer for a few seconds, human recombinant ACE- 2 was then injected at a concentration of $5 \mu \mathrm{g} / \mathrm{mL}$ for 10 minutes. If antibodies blocking the interaction of human recombinant ACE-2 with spike were present, a lower SPR response was recorded; signals were compared to a positive and a negative control run in the other two channels. The positive control consisted of an identical SPR chip but using a SARS-COV-2-negative, pooled commercial serum and for which human recombinant ACE-2 was then injected to obtain the maximum SPR signal from the human recombinant ACE-2-spike interaction. The negative control consisted in the injection of the same serum sample diluted 1:5 with running buffer as in the measurement channels, but with the injection of running buffer (no human recombinant ACE-2) in otherwise identical conditions; the background response was subtracted from the measurements. No heat treatment was applied to the sera to ensure native conditions for the measurement of pseudoneutralization.

\section{Clinical samples}

Sera from the same cohort of individuals as previously reported were used in this study.(30) Adult volunteers (14 males and 18 females) were recruited after written informed consent by the Centre Hospitalier Universitaire de Québec - Université Laval (CHUL, ethics registration number 2021-5241) in Quebec City, Canada. Volunteers recruited in each age group were 18-49, 50-59, 60-69 and 70+ years of age at the time of enrollment and had received a PCR-positive diagnostic for COVID-19 four weeks prior to 
serum collection. Of these, eight samples were randomly selected in each age groups and the same volunteers were recalled for a second blood draw 16 weeks post infection. In one case, a volunteer in the 60-69 age group did not provide a sample on week 16 , resulting in $n=7$ for that data point. All volunteers were considered mildly symptomatic or asymptomatic, as none were hospitalized. Before each visit, the volunteers had no symptoms of fever or dyspnea for at least $48 \mathrm{~h}$ prior to sampling, with little or no cough. Negative controls were collected from eight individuals (age range: 20-55 and median: 47.5 years of age, 7 females and 1 male) having never received a COVID-positive test. Blood samples were collected and processed to obtain the sera as previously described.(30) Enrollment was completed prior to October

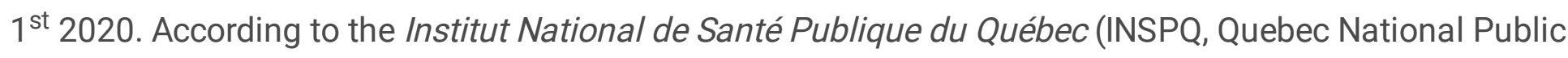
Health Institute), the local public health authority where the study was conducted, the first cases of the B.1.351 VOC was reported in early February 2021.(59) Hence, all individuals in the current study were infected with the native SARS-CoV-2 strain originating from Wuhan. In all cases, sera from 8 individuals in the following age groups (18-49, 50-59, 60-69 and 70+ years old) were compared to 8 negative controls from individuals with no confirmed exposure to SARS-CoV-2.

Statistics

Statistical values (AUC and p-values) were calculated with GraphPad Prism version 9.1.0. Means were compared with paired or unpaired two-tailed t-tests when appropriate.

\section{Declarations}

\section{Acknowledgements}

The authors acknowledge financial support from the Canadian Institutes of Health Research (CIHR), the Natural Sciences and Engineering Research Council of Canada (NSERC), the Pandemic Response Challenge Program of the National Research Council Canada and the Canadian Foundation for Innovation (CFI).

Note: J.-F.M. and J.N.P. have financial interest in Affinité Instruments. The authors declare that they have no other competing interests.

\section{ASSOCIATED CONTENT}

\section{Supporting Information}

The supporting information is available free of charge on the website.

Detailed experimental protocols for the optimization of the SPR protocol. Supplementary tables with raw data for antibody binding for SARS-CoV-2, for the binding kinetics and for the SPR inhibition assay. Figures for the raw data of the SPR and ELISA antibody binding. ELISA and SPR data ROC curves, SPR and ELISA data for different age groups, SPR curves for affinity and for the optimization of the inhibition assay (PDF). 


\section{References}

1. P. Zhou, X.-L. Yang, X.-G. Wang, B. Hu, L. Zhang, W. Zhang, H.-R. Si, Y. Zhu, B. Li, C.-L. Huang, H.-D. Chen, J. Chen, Y. Luo, H. Guo, R.-D. Jiang, M.-Q. Liu, Y. Chen, X.-R. Shen, X. Wang, X.-S. Zheng, K. Zhao, Q.J. Chen, F. Deng, L.-L. Liu, B. Yan, F.-X. Zhan, Y.-Y. Wang, G.-F. Xiao, Z.-L. Shi, A pneumonia outbreak associated with a new coronavirus of probable bat origin. Nature 579, 270-273 (2020).

2. M. A. C. Huergo, N. T. K. Thanh, Current advances in the detection of COVID-19 and evaluation of the humoral response. Analyst 146, 382-402 (2021).

3. J. L. McKechnie, C. A. Blish, The Innate Immune System: Fighting on the Front Lines or Fanning the Flames of COVID-19? Cell Host \& Microbe 27, 863-869 (2020).

4. J. Wu, B. Liang, C. Chen, H. Wang, Y. Fang, S. Shen, X. Yang, B. Wang, L. Chen, Q. Chen, Y. Wu, J. Liu, X. Yang, W. Li, B. Zhu, W. Zhou, H. Wang, S. Li, S. Lu, D. Liu, H. Li, A. Krawczyk, M. Lu, D. Yang, F. Deng, U. Dittmer, M. Trilling, X. Zheng, SARS-CoV-2 infection induces sustained humoral immune responses in convalescent patients following symptomatic COVID-19. Nature Communications 12, 1813 (2021).

5. R. J. Cox, K. A. Brokstad, Not just antibodies: B cells and T cells mediate immunity to COVID-19. Nature Reviews Immunology 20, 581-582 (2020).

6. Y. Galipeau, M. Greig, G. Liu, M. Driedger, M.-A. Langlois, Humoral Responses and Serological Assays in SARS-CoV-2 Infections. Frontiers in Immunology 11, 3382 (2020).

7. L. Guo, L. Ren, S. Yang, M. Xiao, D. Chang, F. Yang, C. S. Dela Cruz, Y. Wang, C. Wu, Y. Xiao, L. Zhang, L. Han, S. Dang, Y. Xu, Q.-W. Yang, S.-Y. Xu, H.-D. Zhu, Y.-C. Xu, Q. Jin, L. Sharma, L. Wang, J. Wang, Profiling Early Humoral Response to Diagnose Novel Coronavirus Disease (COVID-19). Clinical Infectious Diseases 71, 778-785 (2020).

8. S. P. Anand, J. Prévost, M. Nayrac, G. Beaudoin-Bussières, M. Benlarbi, R. Gasser, N. Brassard, A. Laumaea, S. Y. Gong, C. Bourassa, E. Brunet-Ratnasingham, H. Medjahed, G. Gendron-Lepage, G. Goyette, L. Gokool, C. Morrisseau, P. Bégin, V. Martel-Laferrière, C. Tremblay, J. Richard, R. Bazin, R. Duerr, D. E. Kaufmann, A. Finzi, Longitudinal analysis of humoral immunity against SARS-CoV-2 Spike in convalescent individuals up to 8 months post-symptom onset. bioRxiv, 2021.2001.2025.428097 (2021).

9. Q.-X. Long, X.-J. Tang, Q.-L. Shi, Q. Li, H.-J. Deng, J. Yuan, J.-L. Hu, W. Xu, Y. Zhang, F.-J. Lv, K. Su, F. Zhang, J. Gong, B. Wu, X.-M. Liu, J.-J. Li, J.-F. Qiu, J. Chen, A.-L. Huang, Clinical and immunological assessment of asymptomatic SARS-CoV-2 infections. Nature Medicine 26, 1200-1204 (2020).

10. S. Ravichandran, Y. Lee, G. Grubbs, E. M. Coyle, L. Klenow, O. Akasaka, M. Koga, E. Adachi, M. Saito, I. Nakachi, T. Ogura, R. Baba, M. Ito, M. Kiso, A. Yasuhara, S. Yamada, Y. Sakai-Tagawa, K. IwatsukiHorimoto, M. Imai, S. Yamayoshi, H. Yotsuyanagi, Y. Kawaoka, S. Khurana, Longitudinal antibody 
repertoire in "mild" versus "severe" COVID-19 patients reveals immune markers associated with disease severity and resolution. Science Advances 7, eabf2467 (2021).

11. J. Prévost, R. Gasser, G. Beaudoin-Bussières, J. Richard, R. Duerr, A. Laumaea, S. P. Anand, G. Goyette, M. Benlarbi, S. Ding, H. Medjahed, A. Lewin, J. Perreault, T. Tremblay, G. Gendron-Lepage, N. Gauthier, M. Carrier, D. Marcoux, A. Piché, M. Lavoie, A. Benoit, V. Loungnarath, G. Brochu, E. Haddad, H. D. Stacey, M. S. Miller, M. Desforges, P. J. Talbot, G. T. G. Maule, M. Côté, C. Therrien, B. Serhir, R. Bazin, M. Roger, A. Finzi, Cross-Sectional Evaluation of Humoral Responses against SARS-CoV-2 Spike. Cell Reports Medicine 1, 100126 (2020).

12. S. J. Zost, P. Gilchuk, J. B. Case, E. Binshtein, R. E. Chen, J. P. Nkolola, A. Schäfer, J. X. Reidy, A. Trivette, R. S. Nargi, R. E. Sutton, N. Suryadevara, D. R. Martinez, L. E. Williamson, E. C. Chen, T. Jones, S. Day, L. Myers, A. O. Hassan, N. M. Kafai, E. S. Winkler, J. M. Fox, S. Shrihari, B. K. Mueller, J. Meiler, A. Chandrashekar, N. B. Mercado, J. J. Steinhardt, K. Ren, Y.-M. Loo, N. L. Kallewaard, B. T. McCune, S. P. Keeler, M. J. Holtzman, D. H. Barouch, L. E. Gralinski, R. S. Baric, L. B. Thackray, M. S. Diamond, R. H. Carnahan, J. E. Crowe, Potently neutralizing and protective human antibodies against SARS-CoV-2. Nature 584, 443-449 (2020).

13. L. Dai, G. F. Gao, Viral targets for vaccines against COVID-19. Nature Reviews Immunology 21, 73$82(2021)$.

14. E. J. Snijder, R. W. A. L. Limpens, A. H. de Wilde, A. W. M. de Jong, J. C. Zevenhoven-Dobbe, H. J. Maier, F. F. G. A. Faas, A. J. Koster, M. Bárcena, A unifying structural and functional model of the coronavirus replication organelle: Tracking down RNA synthesis. PLOS Biology 18, e3000715 (2020).

15. L. a. Alanagreh, F. Alzoughool, M. Atoum, The Human Coronavirus Disease COVID-19: Its Origin, Characteristics, and Insights into Potential Drugs and Its Mechanisms. Pathogens 9, (2020).

16. M. Letko, A. Marzi, V. Munster, Functional assessment of cell entry and receptor usage for SARSCoV-2 and other lineage B betacoronaviruses. Nature Microbiology 5, 562-569 (2020).

17. A. E. Nel, J. F. Miller, Nano-Enabled COVID-19 Vaccines: Meeting the Challenges of Durable Antibody Plus Cellular Immunity and Immune Escape. ACS Nano, (2021).

18. K. O. Saunders, E. Lee, R. Parks, D. R. Martinez, D. Li, H. Chen, R. J. Edwards, S. Gobeil, M. Barr, K. Mansouri, S. M. Alam, L. L. Sutherland, F. Cai, A. M. Sanzone, M. Berry, K. Manne, K. W. Bock, M. Minai, B. M. Nagata, A. B. Kapingidza, M. Azoitei, L. V. Tse, T. D. Scobey, R. L. Spreng, R. W. Rountree, C. T. DeMarco, T. N. Denny, C. W. Woods, E. W. Petzold, J. Tang, T. H. Oguin, G. D. Sempowski, M. Gagne, D. C. Douek, M. A. Tomai, C. B. Fox, R. Seder, K. Wiehe, D. Weissman, N. Pardi, H. Golding, S. Khurana, P. Acharya, H. Andersen, M. G. Lewis, I. N. Moore, D. C. Montefiori, R. S. Baric, B. F. Haynes, Neutralizing antibody vaccine for pandemic and pre-emergent coronaviruses. Nature, (2021). 
19. L. J. Abu-Raddad, H. Chemaitelly, A. A. Butt, Effectiveness of the BNT162b2 Covid-19 Vaccine against the B.1.1.7 and B.1.351 Variants. New England Journal of Medicine, (2021).

20. S. S. Abdool Karim, T. de Oliveira, New SARS-CoV-2 Variants - Clinical, Public Health, and Vaccine Implications. New England Journal of Medicine 384, 1866-1868 (2021).

21. A. J. Greaney, T. N. Starr, P. Gilchuk, S. J. Zost, E. Binshtein, A. N. Loes, S. K. Hilton, J. Huddleston, R. Eguia, K. H. D. Crawford, A. S. Dingens, R. S. Nargi, R. E. Sutton, N. Suryadevara, P. W. Rothlauf, Z. Liu, S. P. J. Whelan, R. H. Carnahan, J. E. Crowe, J. D. Bloom, Complete Mapping of Mutations to the SARSCoV-2 Spike Receptor-Binding Domain that Escape Antibody Recognition. Cell Host \& Microbe 29, 4457.e49 (2021).

22. A. Baum, B. O. Fulton, E. Wloga, R. Copin, K. E. Pascal, V. Russo, S. Giordano, K. Lanza, N. Negron, M. Ni, Y. Wei, G. S. Atwal, A. J. Murphy, N. Stahl, G. D. Yancopoulos, C. A. Kyratsous, Antibody cocktail to SARS-CoV-2 spike protein prevents rapid mutational escape seen with individual antibodies. Science $\mathbf{3 6 9}$, 1014 (2020).

23. Z. Wang, F. Schmidt, Y. Weisblum, F. Muecksch, C. O. Barnes, S. Finkin, D. Schaefer-Babajew, M. Cipolla, C. Gaebler, J. A. Lieberman, T. Y. Oliveira, Z. Yang, M. E. Abernathy, K. E. Huey-Tubman, A. Hurley, M. Turroja, K. A. West, K. Gordon, K. G. Millard, V. Ramos, J. Da Silva, J. Xu, R. A. Colbert, R. Patel, J. Dizon, C. Unson-O'Brien, I. Shimeliovich, A. Gazumyan, M. Caskey, P. J. Bjorkman, R. Casellas, T. Hatziioannou, P. D. Bieniasz, M. C. Nussenzweig, mRNA vaccine-elicited antibodies to SARS-CoV-2 and circulating variants. Nature 592, 616-622 (2021).

24. C. K. Wibmer, F. Ayres, T. Hermanus, M. Madzivhandila, P. Kgagudi, B. Oosthuysen, B. E. Lambson, T. de Oliveira, M. Vermeulen, K. van der Berg, T. Rossouw, M. Boswell, V. Ueckermann, S. Meiring, A. von Gottberg, C. Cohen, L. Morris, J. N. Bhiman, P. L. Moore, SARS-CoV-2 501Y.V2 escapes neutralization by South African COVID-19 donor plasma. Nature Medicine 27, 622-625 (2021).

25. G. Nelson, O. Buzko, P. Spilman, K. Niazi, S. Rabizadeh, P. Soon-Shiong, Molecular dynamic simulation reveals E484K mutation enhances spike RBD-ACE2 affinity and the combination of E484K, K417N and N501Y mutations (501Y.V2 variant) induces conformational change greater than N501Y mutant alone, potentially resulting in an escape mutant. bioRxiv, 2021.2001.2013.426558 (2021).

26. Y. Tian, C. Lian, Y. Chen, D. Wei, X. Zhang, Y. Ling, Y. Wang, L.-S. Yeap, Sensitivity and specificity of SARS-CoV-2 S1 subunit in COVID-19 serology assays. Cell Discovery 6, 75 (2020).

27. L. Liu, P. Wang, M. S. Nair, J. Yu, M. Rapp, Q. Wang, Y. Luo, J. F. W. Chan, V. Sahi, A. Figueroa, X. V. Guo, G. Cerutti, J. Bimela, J. Gorman, T. Zhou, Z. Chen, K.-Y. Yuen, P. D. Kwong, J. G. Sodroski, M. T. Yin, Z. Sheng, Y. Huang, L. Shapiro, D. D. Ho, Potent neutralizing antibodies against multiple epitopes on SARSCoV-2 spike. Nature 584, 450-456 (2020). 
28. X. Chi, R. Yan, J. Zhang, G. Zhang, Y. Zhang, M. Hao, Z. Zhang, P. Fan, Y. Dong, Y. Yang, Z. Chen, Y. Guo, J. Zhang, Y. Li, X. Song, Y. Chen, L. Xia, L. Fu, L. Hou, J. Xu, C. Yu, J. Li, Q. Zhou, W. Chen, A neutralizing human antibody binds to the N-terminal domain of the Spike protein of SARS-CoV-2. Science 369,650 (2020).

29. C. W. Tan, W. N. Chia, X. Qin, P. Liu, M. I. C. Chen, C. Tiu, Z. Hu, V. C.-W. Chen, B. E. Young, W. R. Sia, Y.-J. Tan, R. Foo, Y. Yi, D. C. Lye, D. E. Anderson, L.-F. Wang, A SARS-CoV-2 surrogate virus neutralization test based on antibody-mediated blockage of ACE2-spike protein-protein interaction. Nature Biotechnology 38, 1073-1078 (2020).

30. A. Djaileb, M. H. Jodaylami, J. Coutu, P. Ricard, M. Lamarre, L. Rochet, D. M. S. Cellier-Goetghebeur, B. Charron, V. Thibault, K. Stevenson, S. Forest, L. S. Live, N. Abonnenc, A. Guedon, P. Quessy, J.-F. Lemay, O. Farnos, A. A. Kamen, M. Stuible, C. Gervais, Y. Durocher, F. Cholette, C. Mesa, J. Kim, M.-P. Cayer, M.-J. De Grandmont, D. Brouard, S. Trottier, D. Boudreau, J. N. Pelletier, J.-F. Masson, Cross-Validation of ELISA and a Portable Surface Plasmon Resonance Instrument for IgG Antibodies Serology with SARS-CoV-2 Positive Individuals ChemRXiv, doi:10.26434/chemrxiv.14347013.v14347011. (2021).

31. R. B. M. Schasfoort, J. van Weperen, M. van Amsterdam, J. Parisot, J. Hendriks, M. Koerselman, M. Karperien, A. Mentink, M. Bennink, H. Krabbe, L. W. M. M. Terstappen, A. H. L. Mulder, Presence and strength of binding of IgM, IgG and IgA antibodies against SARS-CoV-2 during CoViD-19 infection. Biosensors and Bioelectronics, 113165 (2021).

32. S. N. Walker, N. Chokkalingam, E. L. Reuschel, M. Purwar, Z. Xu, E. N. Gary, K. Y. Kim, M. Helble, K. Schultheis, J. Walters, S. Ramos, K. Muthumani, T. R. F. Smith, K. E. Broderick, P. Tebas, A. Patel, D. B. Weiner, D. W. Kulp, SARS-CoV-2 Assays To Detect Functional Antibody Responses That Block ACE2 Recognition in Vaccinated Animals and Infected Patients. Journal of Clinical Microbiology 58, e0153301520 (2020).

33. S. Ravichandran, E. M. Coyle, L. Klenow, J. Tang, G. Grubbs, S. Liu, T. Wang, H. Golding, S. Khurana, Antibody signature induced by SARS-CoV-2 spike protein immunogens in rabbits. Science Translational Medicine 12, eabc3539 (2020).

34. F. Tian, B. Tong, L. Sun, S. Shi, B. Zheng, Z. Wang, X. Dong, P. Zheng, Mutation N501Y in RBD of Spike Protein Strengthens the Interaction between COVID-19 and its Receptor ACE2. bioRxiv, 2021.2002.2014.431117 (2021).

35. J. Perreault, T. Tremblay, M.-J. Fournier, M. Drouin, G. Beaudoin-Bussières, J. Prévost, A. Lewin, P. Bégin, A. Finzi, R. Bazin, Waning of SARS-CoV-2 RBD antibodies in longitudinal convalescent plasma samples within 4 months after symptom onset. Blood 136, 2588-2591 (2020).

36. D. Stadlbauer, F. Amanat, V. Chromikova, K. Jiang, S. Strohmeier, G. A. Arunkumar, J. Tan, D. Bhavsar, C. Capuano, E. Kirkpatrick, P. Meade, R. N. Brito, C. Teo, M. McMahon, V. Simon, F. Krammer, 
SARS-CoV-2 Seroconversion in Humans: A Detailed Protocol for a Serological Assay, Antigen Production, and Test Setup. Current Protocols in Microbiology 57, e100 (2020).

37. P. Wang, L. Liu, S. Iketani, Y. Luo, Y. Guo, M. Wang, J. Yu, B. Zhang, P. D. Kwong, B. S. Graham, J. R. Mascola, J. Y. Chang, M. T. Yin, M. Sobieszczyk, C. A. Kyratsous, L. Shapiro, Z. Sheng, M. S. Nair, Y. Huang, D. D. Ho, Increased Resistance of SARS-CoV-2 Variants B.1.351 and B.1.1.7 to Antibody Neutralization. bioRxiv, 2021.2001.2025.428137 (2021).

38. F. Amanat, D. Stadlbauer, S. Strohmeier, T. H. O. Nguyen, V. Chromikova, M. McMahon, K. Jiang, G. A. Arunkumar, D. Jurczyszak, J. Polanco, M. Bermudez-Gonzalez, G. Kleiner, T. Aydillo, L. Miorin, D. S. Fierer, L. A. Lugo, E. M. Kojic, J. Stoever, S. T. H. Liu, C. Cunningham-Rundles, P. L. Felgner, T. Moran, A. García-Sastre, D. Caplivski, A. C. Cheng, K. Kedzierska, O. Vapalahti, J. M. Hepojoki, V. Simon, F. Krammer, A serological assay to detect SARS-CoV-2 seroconversion in humans. Nature Medicine 26, 1033-1036 (2020).

39. J. F. Masson, Surface Plasmon Resonance Clinical Biosensors for Medical Diagnostics. Acs Sensors 2, 16-30 (2017).

40. S. Khurana, E. M. Coyle, M. Dimitrova, F. Castellino, K. Nicholson, G. Del Giudice, H. Golding, Heterologous Prime-Boost Vaccination with MF59-Adjuvanted H5 Vaccines Promotes Antibody Affinity Maturation towards the Hemagglutinin HA1 Domain and Broad H5N1 Cross-Clade Neutralization. Plos One 9, (2014).

41. B. Ju, Q. Zhang, J. Ge, R. Wang, J. Sun, X. Ge, J. Yu, S. Shan, B. Zhou, S. Song, X. Tang, J. Yu, J. Lan, J. Yuan, H. Wang, J. Zhao, S. Zhang, Y. Wang, X. Shi, L. Liu, J. Zhao, X. Wang, Z. Zhang, L. Zhang, Human neutralizing antibodies elicited by SARS-CoV-2 infection. Nature 584, 115-119 (2020).

42. F. Wu, M. Liu, A. Wang, L. Lu, Q. Wang, C. Gu, J. Chen, Y. Wu, S. Xia, Y. Ling, Y. Zhang, J. Xun, R. Zhang, Y. Xie, S. Jiang, T. Zhu, H. Lu, Y. Wen, J. Huang, Evaluating the Association of Clinical Characteristics With Neutralizing Antibody Levels in Patients Who Have Recovered From Mild COVID-19 in Shanghai, China. JAMA Internal Medicine 180, 1356-1362 (2020).

43. H. S. Yang, V. Costa, S. E. Racine-Brzostek, K. P. Acker, J. Yee, Z. Chen, M. Karbaschi, R. Zuk, S. Rand, A. Sukhu, P. J. Klasse, M. M. Cushing, A. Chadburn, Z. Zhao, Association of Age With SARS-CoV-2 Antibody Response. JAMA Network Open 4, e214302-e214302 (2021).

44. L. Stamatatos, J. Czartoski, Y.-H. Wan, L. J. Homad, V. Rubin, H. Glantz, M. Neradilek, E. Seydoux, M. F. Jennewein, A. J. MacCamy, J. Feng, G. Mize, S. C. De Rosa, A. Finzi, M. P. Lemos, K. W. Cohen, Z. Moodie, M. J. McElrath, A. T. McGuire, mRNA vaccination boosts cross-variant neutralizing antibodies elicited by SARS-CoV-2 infection. Science, eabg9175 (2021).

45. A. Ghaffari, R. Meurant, A. Ardakani, COVID-19 Serological Tests: How Well Do They Actually Perform? Diagnostics 10, (2020). 
46. C. Gaebler, Z. Wang, J. C. C. Lorenzi, F. Muecksch, S. Finkin, M. Tokuyama, A. Cho, M. Jankovic, D. Schaefer-Babajew, T. Y. Oliveira, M. Cipolla, C. Viant, C. O. Barnes, Y. Bram, G. Breton, T. Hägglöf, P. Mendoza, A. Hurley, M. Turroja, K. Gordon, K. G. Millard, V. Ramos, F. Schmidt, Y. Weisblum, D. Jha, M. Tankelevich, G. Martinez-Delgado, J. Yee, R. Patel, J. Dizon, C. Unson-O’Brien, I. Shimeliovich, D. F. Robbiani, Z. Zhao, A. Gazumyan, R. E. Schwartz, T. Hatziioannou, P. J. Bjorkman, S. Mehandru, P. D. Bieniasz, M. Caskey, M. C. Nussenzweig, Evolution of antibody immunity to SARS-CoV-2. Nature, 591, 639-644 (2021).

47. B. Isho, K. T. Abe, M. Zuo, A. J. Jamal, B. Rathod, J. H. Wang, Z. Li, G. Chao, O. L. Rojas, Y. M. Bang, A. Pu, N. Christie-Holmes, C. Gervais, D. Ceccarelli, P. Samavarchi-Tehrani, F. Guvenc, P. Budylowski, A. Li, A. Paterson, F. Y. Yue, L. M. Marin, L. Caldwell, J. L. Wrana, K. Colwill, F. Sicheri, S. Mubareka, S. D. GrayOwen, S. J. Drews, W. L. Siqueira, M. Barrios-Rodiles, M. Ostrowski, J. M. Rini, Y. Durocher, A. J. McGeer, J. L. Gommerman, A.-C. Gingras, Persistence of serum and saliva antibody responses to SARS-CoV-2 spike antigens in COVID-19 patients. Science Immunology 5, eabe5511 (2020).

48. A. Wajnberg, F. Amanat, A. Firpo, D. R. Altman, M. J. Bailey, M. Mansour, M. McMahon, P. Meade, D. R. Mendu, K. Muellers, D. Stadlbauer, K. Stone, S. Strohmeier, V. Simon, J. Aberg, D. L. Reich, F. Krammer, C. Cordon-Cardo, Robust neutralizing antibodies to SARS-CoV-2 infection persist for months. Science 370, 1227 (2020).

49. C. Liu, X. Yu, C. Gao, L. Zhang, H. Zhai, Y. Hu, E. Liu, Q. Wang, Y. Gao, D. Wei, D. Zhang, Y. Han, X. Zhang, Characterization of antibody responses to SARS-CoV-2 in convalescent COVID-19 patients. Journal of Medical Virology 93, 2227-2233 (2021).

50. R. Gasser, M. Cloutier, J. Prévost, C. Fink, É. Ducas, S. Ding, N. Dussault, P. Landry, T. Tremblay, A. Laforce-Lavoie, A. Lewin, G. Beaudoin-Bussières, A. Laumaea, H. Medjahed, C. Larochelle, J. Richard, G. A. Dekaban, J. D. Dikeakos, R. Bazin, A. Finzi, Major role of IgM in the neutralizing activity of convalescent plasma against SARS-CoV-2. Cell Reports 34, 108790 (2021).

51. J. Seow, C. Graham, B. Merrick, S. Acors, S. Pickering, K. J. A. Steel, O. Hemmings, A. O’Byrne, N. Kouphou, R. P. Galao, G. Betancor, H. D. Wilson, A. W. Signell, H. Winstone, C. Kerridge, I. Huettner, J. M. Jimenez-Guardeño, M. J. Lista, N. Temperton, L. B. Snell, K. Bisnauthsing, A. Moore, A. Green, L. Martinez, B. Stokes, J. Honey, A. Izquierdo-Barras, G. Arbane, A. Patel, M. K. I. Tan, L. O’Connell, G. O’Hara, E. MacMahon, S. Douthwaite, G. Nebbia, R. Batra, R. Martinez-Nunez, M. Shankar-Hari, J. D. Edgeworth, S. J. D. Neil, M. H. Malim, K. J. Doores, Longitudinal observation and decline of neutralizing antibody responses in the three months following SARS-CoV-2 infection in humans. Nature Microbiology 5, 15981607 (2020).

52. L. Grzelak, A. Velay, Y. Madec, F. Gallais, I. Staropoli, C. Schmidt-Mutter, M.-J. Wendling, N. Meyer, C. Planchais, D. Rey, H. Mouquet, L. Glady, Y. Hansmann, T. Bruel, J. De Sèze, A. Fontanet, M. Gonzalez, O. Schwartz, S. Fafi-Kremer, Sex differences in the decline of neutralizing antibodies to SARS-CoV-2. medRxiv, 2020.2011.2012.20230466 (2020). 
53. H. Harvala, M. L. Robb, N. Watkins, S. Ijaz, S. Dicks, M. Patel, P. Supasa, D. Wanwisa, C. Liu, J. Mongkolsapaya, A. Bown, D. Bailey, R. Vipond, N. Grayson, N. Temperton, S. Gupta, R. J. Ploeg, J. Bolton, A. Fyfe, R. Gopal, P. Simmonds, G. Screaton, C. Thompson, T. Brooks, M. Zambon, G. Miflin, D. J. Roberts, Convalescent plasma therapy for the treatment of patients with COVID-19: Assessment of methods available for antibody detection and their correlation with neutralising antibody levels. Transfusion Medicine n/a, (2020).

54. C. H. GeurtsvanKessel, N. M. A. Okba, Z. Igloi, C. W. E. Embregts, B. M. Laksono, L. Leijten, J. Rahamat-Langendoen, J. P. C. van den Akker, J. J. A. van Kampen, A. A. van der Eijk, R. S. van Binnendijk, B. Haagmans, M. Koopmans, Towards the next phase: evaluation of serological assays for diagnostics and exposure assessment. medRxiv, 2020.2004.2023.20077156 (2020).

55.

56. M. Stuible, C. Gervais, S. Lord-Dufour, S. Perret, D. L'Abbé, J. Schrag, G. St-Laurent, Y. Durocher, Rapid, high-yield production of full-length SARS-CoV-2 spike ectodomain by transient gene expression in $\mathrm{CHO}$ cells. Journal of Biotechnology, (2020).

57. J. Perreault, T. Tremblay, M. J. Fournier, M. Drouin, G. Beaudoin-Bussieres, J. Prevost, A. Lewin, P. Begin, A. Finzi, R. Bazin, Waning of SARS-CoV-2 RBD antibodies in longitudinal convalescent plasma samples within 4 months after symptom onset. Blood 136, 2588-2591 (2020).

58. S. S. Zhao, N. Bukar, J. L. Toulouse, D. Pelechacz, R. Robitaille, J. N. Pelletier, J. F. Masson, Miniature multi-channel SPR instrument for methotrexate monitoring in clinical samples. Biosensors \& Bioelectronics 64, 664-670 (2015).

59. . vol. 2021.

\section{Tables}

Table 1. ELISA for the detection of IgG targeting the native and B.1.351 spike proteins using serum from variant-naïve, SARS-CoV-2-positive individuals at weeks 4 and 16 post-diagnosis 


\begin{tabular}{l|c|cc|cc}
\multicolumn{2}{l|}{} & \multicolumn{2}{c|}{ Native spike } & \multicolumn{2}{c}{ B.1.351 spike } \\
\hline ELISA & & Week 4 & Week 16 & Week 4 & Week 16 \\
OD $_{450}$ (A.U) & Pos. & $2.0 \pm 0.7$ & $1.6 \pm 0.6$ & $1.4 \pm 0.7$ & $1.5 \pm 0.8$ \\
OD $_{\mathbf{4 5 0} \text { (A.U) }}$ & Neg. & $0.18 \pm 0.04$ & $0.32 \pm 0.11$ & $0.16 \pm 0.04$ & $0.17 \pm 0.05$ \\
Threshold (A.U) & & 0.4 & 0.6 & 0.25 & 0.2 \\
COVID+ sera & \# Pos. & 32 & 31 & 32 & 31 \\
& \# Neg. & 0 & 0 & 0 & 0 \\
Control sera & \# Pos. & 0 & 0 & 0 & 0 \\
& \# Neg. & 8 & 8 & 8 & 8 \\
AUC & & 1.00 & 1.00 & 1.00 & 1.00 \\
p value & & 0.0001 & $<0.0001$ & $<0.0001$ & $<0.0001$ \\
Sensitivity & & 100 & 100 & 100 & 100 \\
Specificity & & 100 & 100 & 100 & 100 \\
\hline
\end{tabular}

Table 2. SPR assay for the detection of human IgG targeting the native and B.1.351 spike proteins using serum from variant-naïve, SARS-CoV-2-positive individuals at weeks 4 and 16 post-diagnosis

\begin{tabular}{|c|c|c|c|c|c|}
\hline & \multicolumn{2}{|c|}{ Native spike } & \multicolumn{2}{|c|}{ B.1.351 spike } \\
\hline & & Week 4 & Week 16 & Week 4 & Week 16 \\
\hline ift (kRU) & Pos. & $1.5 \pm 0.5$ & $1.4 \pm 0.6$ & $1.1 \pm 0.5$ & $1.0 \pm 0.5$ \\
\hline ift (kRU) & Neg. & $0.30 \pm 0.17$ & $0.11 \pm 0.12$ & $0.6 \pm 0.3$ & $0.17 \pm 0.09$ \\
\hline reshold (kRU) & & 0.6 & 0.35 & 0.7 & 0.35 \\
\hline )VID+ sera & \# Pos. & 31 & 31 & 26 & 27 \\
\hline & \# Neg. & 1 & 0 & 6 & 4 \\
\hline ntrol sera & \# Pos. & 0 & 0 & 1 & 0 \\
\hline & \# Neg. & 8 & 8 & 7 & 8 \\
\hline JC & & 0.99 & 0.99 & 0.82 & 0.93 \\
\hline ralue & & $<0.0001$ & $<0.0001$ & $<0.05$ & $<0.0001$ \\
\hline nsitivity & & 97 & 100 & 81 & 87 \\
\hline ecificity & & 100 & 100 & 88 & 100 \\
\hline
\end{tabular}

\section{Figures}
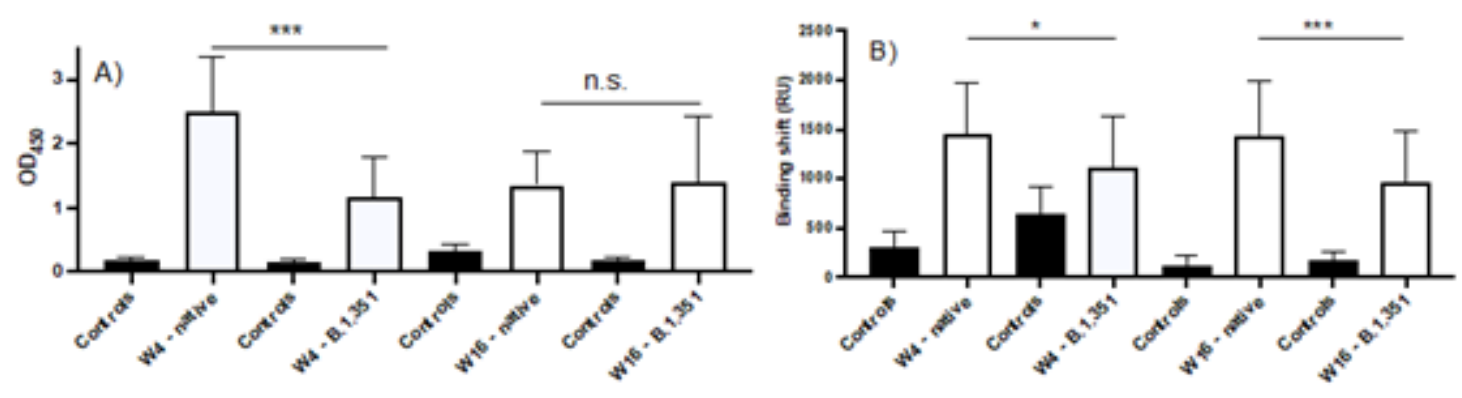

Figure 1 
Average ELISA OD450 (A) and SPR binding shifts (B) for the detection of anti-spike IgG in SARS-CoV-2positive sera $(n=32)$ and negative controls $(n=8)$ at week $4($ W4) and week 16 (W16) post-diagnosis for the native and B.1.351 spike proteins. Error bars represent one standard deviation. n.s. not statistically significant, ${ }^{*} p<0.05$ and ${ }^{* * *} p<0.0001$

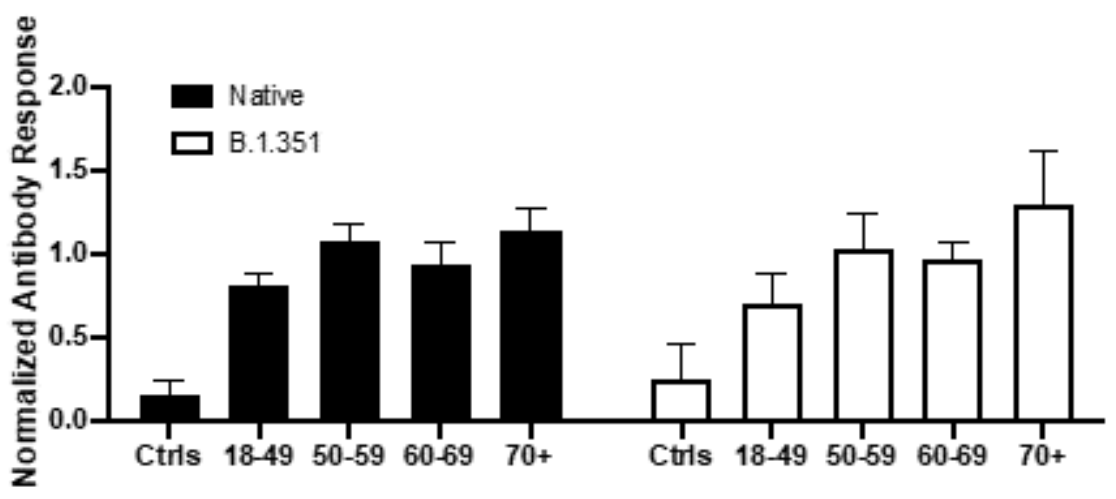

Figure 2

Average normalized antibody binding stratified by age group for human anti-IgGs targeting the native (black) and B.1.351 (white) spike proteins among variant-naïve, non-hospitalized individuals. SPR and ELISA data from weeks 4 and 16 post-diagnosis were normalized to the mean of the overall cohort and pooled. A normalized antibody binding of 1 thus refers to a response equivalent to the average of all SARS-CoV-2-positive individuals ( $\mathrm{n}=8$ for all data sets and the error bars correspond to one standard deviation). Figures S7 (ELISA) and S8 (SPR) report these results separately for each assay and time point. Ctrls: Controls
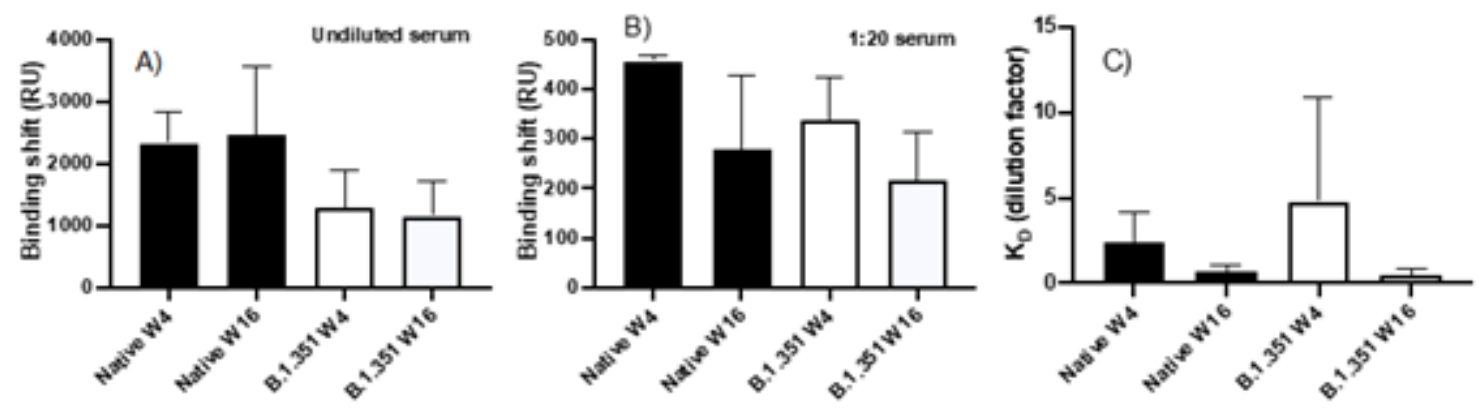

\section{Figure 3}

SPR binding shift for undiluted serum (A) and serum at a 1:20 dilution (B) from SARS-CoV-2-positive individuals at weeks 4 and 16 post-diagnosis for the native (black) and B.1.351 (white) spike proteins. (C) A dissociation constant was estimated from the dilution series assuming a 1:1 binding model according to the data presented in panels $(A)$ and $(B)$. The dilution series used in SPR data acquisition consisted of the following: 1:40, 1:20, 1:10, 1:5, 1:2.5 and undiluted serum. 

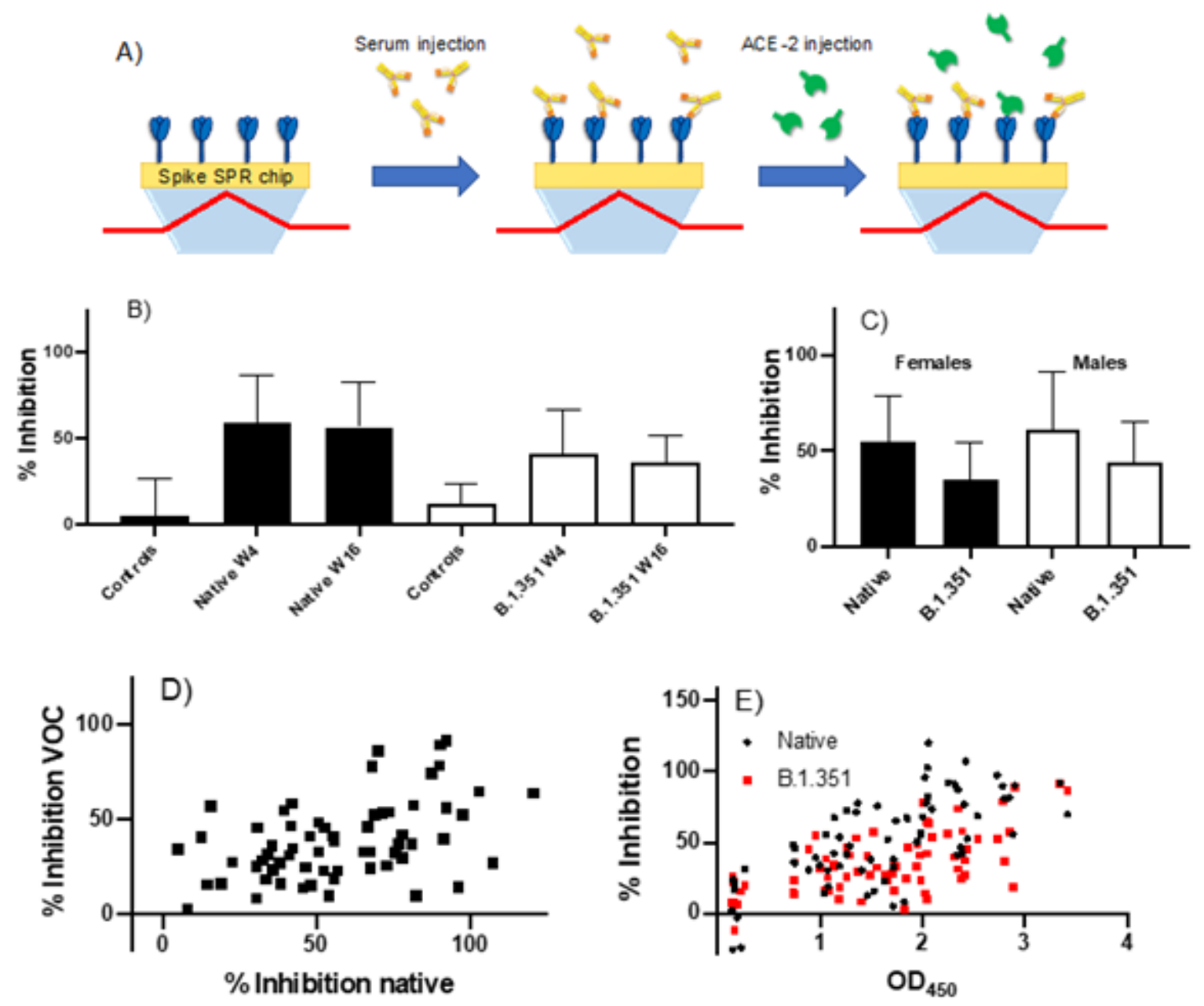

\section{Figure 4}

(A) Schematic illustrating the principle of the SPR pseudo-neutralization assay to quantify the inhibition of the interaction between spike protein and ACE-2 in the presence of SARS-CoV-2-positive sera. A serum from an individual who tested positive for SARS-CoV-2 is injected on an SPR chip that has been functionalized with spike protein, and a preparation of recombinant human ACE-2 is subsequently injected. A reduced SPR response (and thus higher percent inhibition) should be observed if the serum antibodies inhibit the spike - ACE-2 interaction. (B) Observed inhibition of the interaction of ACE-2 with native and B.1.351 spike proteins by variant-naïve SARS-CoV-2-positive sera $(n=32)$. Controls are sera from SARS-CoV-2-negative individuals who were never diagnosed with SARS-CoV-2 $(n=8)$. Error bars represent one standard deviation. (C) Observed inhibition of the interaction of ACE-2 with native and B.1.351 spike proteins by variant-naïve SARS-CoV-2-positive sera as a function of sex (females: $\mathrm{n}=18$; males: $n=14$ ). (D) Correlation between the percent inhibition (for weeks 4 and 16 post-diagnosis combined) observed for native and for the B.1.351 spike proteins; each dot corresponds to an average of 2 replicates for a single individual. (E) Correlation between the ELISA OD450 results (Figure 1 and Table S1) and pseudo-neutralization results for weeks 4 and 16 combined. 


\section{Supplementary Files}

This is a list of supplementary files associated with this preprint. Click to download.

- SISPRELISAvariantsfinal.docx 